Roger Williams University

DOCS@RWU

\title{
Effects of temperature on reproduction and survival of the calanoid copepod Pseudodiaptomus pelagicus
}

Andrew L. Rhyne

Roger Williams University, arhyne@rwu.edu

Cortney L. Ohs

University of Florida

Erik Stenn

AlgaGen LLC

Follow this and additional works at: https://docs.rwu.edu/fcas_fp

Part of the Biology Commons

\section{Recommended Citation}

Rhyne, A.L., C. Ohs, and E. Stenn. 2009. "The Effects of Temperature on Growth, Reproduction, and Production of the Calanoid Copepod, Pseudodiaptomus Pelagicus, a Species with Potential of Mass Production for use in Aquaculture." Aquaculture 292: 53-59.

This Article is brought to you for free and open access by the Arts and Sciences at DOCS@RWU. It has been accepted for inclusion in Arts \& Sciences Faculty Publications by an authorized administrator of DOCS@RWU. For more information, please contact mwu@rwu.edu. 


\title{
Effects of temperature on reproduction and survival of the calanoid copepod Pseudodiaptomus pelagicus
}

\author{
Andrew L. Rhyne ${ }^{\mathrm{a}, *, 2}$, Cortney L. Ohs ${ }^{\mathrm{a}}$, Erik Stenn ${ }^{\mathrm{b}, 1}$ \\ a University of Florida, Indian River Research and Education Center, 2199 South Rock Road, Fort Pierce FL 34945, USA \\ ${ }^{\mathrm{b}}$ AlgaGen LLC, 2336 20th Street, Vero Beach FL 32960, USA
}

\section{A R T I C L E I N F O}

\section{Article history:}

Received 6 September 2008

Received in revised form 18 March 2009

Accepted 21 March 2009

\section{Keywords:}

Calanoid

Copepod

Pseudodiaptomus pelgicus

Temperature

\begin{abstract}
A B S T R A C T
Four experiments were conducted on the calanoid copepod, Pseudodiaptomus pelagicus, to determine the effects of temperature $\left(24,26,28,30,32\right.$, and $\left.34^{\circ} \mathrm{C}\right)$ on survival, development time, reproductive output, and population growth in order to define the optimal temperature for culture. The first experiment stocked early stage nauplii into $1 \mathrm{~L}$ beakers and cultured them using standard procedures until five days after the first mature adults were observed; from this survival, sex ratio, time to maturation, and fecundity were measured. The second and third experiments evaluated the effects of temperature on nauplii production by stocking individual pairs and 25 pairs of adults, respectively; in both experiments nauplii production was determined daily for 10 days. The fourth experiment determined the effects of temperature on population growth and composition of the population produced by stocking 10 adult pairs and culturing them for 10 days at six temperatures. Results indicate survival from early nauplii to adult was significantly affected by temperature and those cultured from $24-30{ }^{\circ} \mathrm{C}$ had the highest mean survival. Time to first maturation and maturation of the entire population was significantly influenced by temperature and took from 6.8 to 12.8 days. Temperature significantly affected nauplii production in both individual and groups of paired adults. Temperature affected the mean daily nauplii production by decreasing the brood interval but did not affect the mean brood size. The number of nauplii produced by 25 adult pairs was significantly influenced by temperature; the optimal temperature was $27.5^{\circ} \mathrm{C}$ at which 1861 nauplii were produced. The distribution of developmental stages in the population was also affected by temperature; at lower temperatures the population consisted of a greater proportion of nauplii while at $32{ }^{\circ} \mathrm{C}$ the population was comprised of more advanced staged individuals. When developing production objectives, aquaculturists must consider temperature because it has multiple effects on the culture of P. pelagicus. The optimal temperature range to achieve high survival and the greatest nauplii production is $26-30{ }^{\circ} \mathrm{C}$. To maintain long-term stock cultures the best temperature may be $24{ }^{\circ} \mathrm{C}$ to slow maturation and growth while $28-32{ }^{\circ} \mathrm{C}$ may be used to maximize nauplii production by decreasing time to maturation and decreasing brood intervals.
\end{abstract}

(c) 2009 Elsevier B.V. All rights reserved.

\section{Introduction}

In the wild, copepods are dominant prey items for the vast majority of marine fish larvae (Hunter, 1981; Leis, 1991; Østergaard et al., 2005; Sampey et al., 2007). Brachionus spp. (rotifers) or Artemia spp. (Artemia) are commonly used in aquaculture because of convenience and commercial availability (Hoff and Snell, 1999). Yet, Artemia nauplii and rotifers are deficient in essential highly unsaturated fatty acids for many larval and juvenile marine fishes without

\footnotetext{
* Corresponding author. Department of Biology and Marine Biology, Roger Williams University, One Old Ferry Road, Bristol, RI 02809, USA. Tel.: +1 401254 5750; fax: +1 401 2543310 .

E-mail addresses: arhyne001@hotmail.com, arhyne@rwu.edu (A.L. Rhyne), cohs@ufl.edu (C.L. Ohs), eriks@algagen.com (E. Stenn).

${ }^{1}$ Tel.: +1772978 1395 .

2 Edgerton Research Laboratory, New England Aquarium, One Central Wharf, Boston, MA 02110, USA.
}

the addition of enrichments. Feeding copepods exclusively or in combination with other live organisms has repeatedly demonstrated superior results in terms of growth, survival, and the overall health of larval fish (Kraul et al., 1992; 1993; Shields et al., 1999; Gardner, 2000; Payne et al., 2001; Støttrup, 2000; Støttrup, 2003; Wilcox et al., 2006). Feeding copepods to larval fish species with small mouth gapes has allowed these species to be successfully cultured through the larval phase (Shields et al., 2003; Shields et al., 2005; Baensch, 2009). Currently, our ability to commercially produce marine fish is generally limited to those species that can be reared on enriched rotifers and Artemia.

Despite the aforementioned advantages of feeding copepods over other live feeds currently in use, the use of copepods in commercial settings is rare. This is primarily due to an inability to produce a reliable, continuous supply of copepods on a largescale (Gapasin and Duray, 2000; Payne and Rippingale, 2001a; Støttrup, 2003). Typical culture densities for calanoid species are 
0.5-1.0/ $\mathrm{mL}$ (Morehead, 2004), whereas rotifers have been reported to achieve a density of $16,000 / \mathrm{mL}$ in intensive recirculating systems (Suantika et al., 2001).

Several species of copepods have shown commercial production potential. Payne and Rippingale (2001a,b) demonstrated successful culture methods for Gladioferens imparipes, and designed a system to produce 1-2 nauplii/mL on a continuous basis. G. imparipes is a small egg bearing estuarine calanoid copepod with a semi-benthic adult life stage (Payne and Rippingale, 2001a). Production of Acartia tonsa continues to be refined (Peck and Holste, 2006). Recent success with the long-term cold storage of $A$. tonsa eggs could prove to be a valuable egg banking method (Drillet et al., 2006; Holmstrup et al., 2006; Drillet et al., 2007). Several small paracalanid species have also recently shown promise for mass scale culture (McKinnon et al., 2003; Shields et al., 2005; Vanderlugt and Lenz, 2008).

In 2003, we isolated the copepod, P. pelagicus, from the waters of south Florida and have kept it in continuous culture for five years. $P$. pelagicus has exhibited culture characteristics very similar to $G$. imparipes, and appears well suited for mass production. Pseudodiaptomus spp. are semi-benthic calanoid copepods; the adults are substrate oriented and nauplii and early copepodites are pelagic (Jacobs, 1961). The genus is globally distributed from tropical to temperate waters (Walter, 1989). Predominantly an estuarine genus, they generally tolerate a wide range of environmental parameters (Chen et al., 2006). Unlike many other calanoids, Pseudodiaptomus spp. appear well suited to culture systems because they can tolerate heavy aeration, tolerate the presence of sediment and suspended solids, grow and reproduce well on a single readily produced microalgae species (Isochrysis galbana), and can achieve densities of over $5 / \mathrm{mL}$ (unpublished data).

Temperature is a key abiotic factor regulating the growth and reproductive potential of copepods in marine systems (Santos et al., 1999; Peterson, 2001; Isla and Perissinotto, 2004; Sullivan et al., 2007; Sun et al., 2008). Additionally, temperature is a key variable in the development of production regimes (Santos et al., 1999; Holste and Peck, 2006; Milione and Zeng, 2008). It is important to identify the impacts of key abiotic factors prior to evaluating diet and other biotic culture conditions. For example, the microalga Rhodomonas lens, commonly fed to copepods, is temperature sensitive and cultures decline or crash at temperatures above $26^{\circ} \mathrm{C}$. Therefore, this nutrient rich species of algae may not be feasible for feeding species of copepods which require higher culture temperatures.

A series of experiments were conducted to measure the effect of temperature on the survival, development time, reproductive output, and population growth of $P$. pelagicus with the overall objective to define the most suitable temperature or range of temperatures for commercial production and future experimentation.

\section{Materials and methods}

\subsection{Stock cultures}

P. pelagicus stock cultures for this experiment were obtained from AlgaGen LLC located in Vero Beach, Florida and were of the strain PP1103. Established standard culture protocols were followed which consisted of culture in $100 \mathrm{~L}$ static tanks at $26^{\circ} \mathrm{C}$ and a salinity of $35 \mathrm{~g} / \mathrm{L}$. Gentle aeration was provided from the bottom of the tank. Water quality was maintained by exchanging $100 \%$ of the culture water every Monday and Thursday. Photoperiod was maintained at $24 \mathrm{~h}$ of light. All copepods were provided a daily ration of Tahitian strain Isochrysis galbana (T-iso) from a stock culture to obtain a feeding density between 2 and $3 \times 10^{5}$ cells $/ \mathrm{mL}$. Unless otherwise stated, experimental culture conditions were maintained during experiments in accordance with the standard protocols developed by AlgaGen LLC described above. Adult copepods were obtained by sieving stock cultures through a $200 \mu$ m nylon screen which retained only adults. Early stage nauplii (N1-N3) were obtained by sieving stock cultures through a $125 \mu \mathrm{m}$ nylon screen, and collecting the nauplii on a $50 \mu \mathrm{m}$ nylon screen.

\subsection{Survival, sex ratio, maturation and fecundity}

To determine the effects of temperature on survival, sex ratio, maturation, and fecundity, a series of experiments were conducted using early stage nauplii obtained from stock cultures at six temperatures $\left(24,26,28,30,32\right.$, and $\left.34{ }^{\circ} \mathrm{C}\right)$. All other experimental conditions were maintained per stock culture protocols. Each temperature treatment was replicated six times and cultures were maintained in a climate controlled room within constant temperature water baths. Each replicate was a covered $1 \mathrm{~L}$ beaker which contained $650 \mathrm{~mL}$ of seawater. Saline water was obtained from the Atlantic Ocean (35-35.5 g/L) and filtered before use. A total of 200 nauplii were volumetrically stocked into each replicate beaker. Volumetric stocking was conducted with a $10 \mathrm{~mL}$ pipette (Eppendorf Model 022472208). To determine the accuracy we conducted counts on 12 volumetric samples taken from a homogenized beaker of nauplii. In these 12 volumetric samples we were able to collect $100 \pm 6.5 \%$ of the desired number of nauplii.

Each day, replicate beakers of copepods were observed to determine the time to first maturity and time to total population maturity. When $P$. pelagicus becomes sexually mature, adults aggregate on the walls of the culture vessel and pair making it relatively easy to determine the level of maturation. Females were considered to be mature when they were carrying their first egg sac (Payne and Rippingale, 2001b). First maturity was defined as when the first female was observed to be carrying eggs. The population was determined to be totally mature when no free swimming copepodites were observed and all females were gravid. Five days after first maturity, the cultures were sieved onto a $50 \mu \mathrm{m}$ screen and then placed in $30 \mathrm{~mL}$ vials and preserved in a $5 \%$ solution of neutral buffered formalin in seawater and stored in a refrigerator $\left(4{ }^{\circ} \mathrm{C}\right)$ until enumeration. The entire population was counted, sexed and the number of ovigerous females was recorded. Survival was calculated by the total number of copepods harvested divided by the number of copepods volumetrically stocked (200). Copepods were sexed by observing the morphologically distinct antennae, females exhibit straight antennaes and males while the right antennule bent; they also exhibit sexual size dimorphism, with the female being about $40 \%$ larger (Grice, 1969). Fecundity was determined by excising both egg sacs with fine forceps and needles from five females per replicate. Egg sac membranes were dissolved by placing each egg sac in a $5 \%$ solution of sodium hyperchlorite and gently agitating. Then the total number of eggs was quantified for each egg sac and each female with a stereomicroscope (Olympus SZ30).

\subsection{Nauplii production}

To determine the effects of temperature on the timing and rate of nauplii production, two separate experiments were conducted to evaluate both group and individual daily nauplii production at the six treatment temperatures. The adult pairs of copepods were obtained from stock cultures at each treatment temperature.

For group production, six replicate enclosures for each treatment were stocked with 25 reproductive adult pairs (male and female attached) and cultured for 10 days. Enclosures were 1 L beakers containing a $350 \mathrm{~mL}$ screen enclosure (165 $\mu \mathrm{m}$ nylon mesh on the bottom of the enclosure) nested inside of the beaker. Daily, the enclosures were removed from the beakers, retaining the adults on the screen, and were immediately placed into a fresh beaker containing temperature acclimated seawater and T-iso. Daily production was determined by counting the nauplii produced during each $24 \mathrm{~h}$ period. 
Table 1

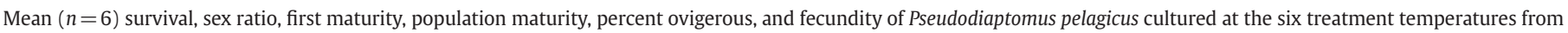
an initial population of 200 nauplii and cultured until five days after observation of the first ovigerous female.

\begin{tabular}{|c|c|c|c|c|c|c|c|c|}
\hline \multirow{2}{*}{$\begin{array}{l}\text { Temperature } \\
\left({ }^{\circ} \mathrm{C}\right)\end{array}$} & \multirow[t]{2}{*}{ Survival (\%) } & \multirow{2}{*}{$\begin{array}{l}\text { Sex ratio } \\
\text { M:F }\end{array}$} & \multirow{2}{*}{$\begin{array}{l}\text { First } \\
\text { maturity } \\
\text { (days) }\end{array}$} & \multirow{2}{*}{$\begin{array}{l}\text { Population } \\
\text { maturity } \\
\text { (days) }\end{array}$} & \multirow{2}{*}{$\begin{array}{l}\text { Ovigerous } \\
(\%)\end{array}$} & \multicolumn{3}{|c|}{ Fecundity } \\
\hline & & & & & & Left egg sac & Right egg sac & Total \\
\hline 24 & $81.3 \pm 22.7^{\mathrm{ab}}$ & $1.1 \pm 0.2^{\mathrm{a}}$ & $10.7 \pm 1.0^{\mathrm{a}}$ & $12.8 \pm 0.4^{\mathrm{a}}$ & $50.5 \pm 15.7^{\mathrm{a}}$ & $12.9 \pm 1.2^{\mathrm{a}}$ & $3.2 \pm 0.9^{\mathrm{a}}$ & $16.2 \pm 1.5^{\mathrm{a}}$ \\
\hline 26 & $86.3 \pm 24.6^{\mathrm{ab}}$ & $1.0 \pm 0.3^{a}$ & $9.3 \pm 1.6^{\mathrm{ab}}$ & $12.0 \pm 0.0^{\mathrm{b}}$ & $11.9 \pm 6.4^{\mathrm{b}}$ & $8.8 \pm 1.0^{\mathrm{b}}$ & $2.0 \pm 0.9^{\mathrm{a}}$ & $10.9 \pm 6.4^{b}$ \\
\hline 28 & $101.8 \pm 9.0^{a}$ & $0.9 \pm 0.2^{a}$ & $7.8 \pm 0.4^{\mathrm{bc}}$ & $10.0 \pm 0.0^{c}$ & $91.2 \pm 6.3^{c}$ & $20.0 \pm 1.2^{c}$ & $5.2 \pm 0.8^{b}$ & $25.2 \pm 1.0^{c}$ \\
\hline 30 & $74.3 \pm 9.8^{\mathrm{ab}}$ & $1.0 \pm 0.2^{a}$ & $6.8 \pm 0.4^{\mathrm{c}}$ & $9.0 \pm 0.0^{d}$ & $78.8 \pm 9.0^{c}$ & $17.7 \pm 1.9^{\mathrm{cd}}$ & $6.0 \pm 0.9^{b}$ & $23.7 \pm 2.3^{\mathrm{cd}}$ \\
\hline 32 & $66.7 \pm 8.9^{b}$ & $1.2 \pm 0.1^{a}$ & $6.7 \pm 0.5^{c}$ & $8.0 \pm 0.0^{\mathrm{e}}$ & $66.7 \pm 10.1^{c}$ & $15.3 \pm 2.2^{\mathrm{ad}}$ & $5.3 \pm 1.0^{\mathrm{b}}$ & $20.6 \pm 2.6^{\text {de }}$ \\
\hline 34 & $62.5 \pm 10.0^{\mathrm{b}}$ & $1.2 \pm 0.2^{a}$ & $6.7 \pm 0.5^{c}$ & $8.0 \pm 0.0^{\mathrm{e}}$ & $53.0 \pm 13.5^{\mathrm{a}}$ & $14.0 \pm 1.8^{\mathrm{a}}$ & $5.0 \pm 1.1^{b}$ & $19.1 \pm 2.1^{\text {ae }}$ \\
\hline
\end{tabular}

Different superscript letters indicate statistical differences $(p \leq 0.05)$ among treatments.

For individual production, reproductive adult pairs were individually held in one of six $30 \mathrm{~mL}$ beakers per treatment, each containing $20 \mathrm{~mL}$ of temperature acclimated seawater and T-iso. Each day the individual pair was captured with a transfer pipette and moved to a new culture vessel containing fresh temperature adjusted seawater and T-iso. Daily nauplii production was determined by counting the number of nauplii produced during each $24 \mathrm{~h}$ period.

For individual production, brood interval was the number of days between broods, measured from the first day nauplii were present in two successive broods. A brood was defined as the production of greater than one nauplii in the $24 \mathrm{~h}$ period between water exchanges. Mean brood size was calculated from all broods during the 10 day experimental culture period.

\subsection{Population dynamics}

To determine the effects of temperature on the development of population composition, 10 reproductive adult pairs were obtained from stock cultures and were stocked into six $1 \mathrm{~L}$ beakers containing $650 \mathrm{~mL}$ of filtered seawater and T-iso at each of the six treatment temperatures. After 10 days following standard culture protocols, the entire population was sieved onto a $50 \mu \mathrm{m}$ screen then placed in $30 \mathrm{~mL}$ vials and preserved in a 5\% neutral buffered formalin and seawater solution and placed in a refrigerator $\left(4^{\circ} \mathrm{C}\right)$ until enumeration. The number of early nauplii, late nauplii (N4-N6), copepodites (C1-C5), and adults (C6) (Grice, 1969) was quantified for each replicate by placing the population on a zooplankton counting wheel and observing each individual with a stereo-microscope.

\subsection{Statistics}

An analysis of variance using the general linear model (PROC GLM) of SAS (SAS, 1999) was used to determine if there were statistically significant differences between treatments for survival, time to first maturity, time to population maturity, percent ovigerous, fecundity, brood interval, brood size, and total nauplii produced. The means were separated by the Tukey's procedure of SAS (SAS, 1999). Statistical significance occurred in all analyses when the calculated $p$-value was $\leq 0.05$. All mean values are reported as mean \pm S.D.

A chi square analysis was conducted on the male:female sex ratio, and when comparing the number of eggs in the left and right egg sacs, to determine if the results were significantly different from the expected 1:1 ratio (SAS, 1999). The regression curves and formulas were generated with Sigma Plot Version 8.0 software (Sigma Plot, 2002).

\section{Results}

\subsection{Survival, sex ratio, maturation and fecundity}

Survival of $P$. pelagicus from early nauplii to adult was significantly $(p=0.004)$ affected by culture temperature (Table 1$)$. Copepods cultured between $24-30{ }^{\circ} \mathrm{C}$ had the higher mean survival than other temperatures and the highest survival of $101.8 \pm 9.0 \%$ was recorded at $28{ }^{\circ} \mathrm{C}$. Survival significantly declined in the $32{ }^{\circ} \mathrm{C}$ and $34{ }^{\circ} \mathrm{C}$ treatments to $66.7 \pm 8.9 \%$ and $62.5 \pm 10.0 \%$, respectively. Sex ratios of the final populations did not significantly $(p>0.05)$ differ from the expected $1: 1$ male:female ratio and the six treatments were not significantly different from each other $(p=0.0869)$. Time to the first reproductive female and to the total population maturity was strongly influenced by temperature. Development time from an early nauplii stage to the first observed reproductive female was highly significant $(p<0.0001)$ and ranged from $10.7 \pm 1.0$ days to $6.7 \pm 0.5$ days and followed a decreasing trend with increasing temperature. Likewise, time to total population maturity was significantly influenced $(p<0.0001)$ by temperature, taking $12.8 \pm 0.4$ days at $24{ }^{\circ} \mathrm{C}$ and $8.0 \pm 0.0$ days at $34{ }^{\circ} \mathrm{C}$. Fecundity was significantly affected $(p<0.0001)$ by rearing temperature, ranging from $25.2 \pm 1.0$ eggs to $16.2 \pm 1.5$ eggs per female, with the highest fecundity measured at 28 and $30^{\circ} \mathrm{C}$. In all treatments, females always had a greater number of eggs in their left egg sac compared to their right $(p<0.0001)$. At the time of sampling the 28 and $30{ }^{\circ} \mathrm{C}$ treatments displayed a significantly higher $(p<0.0001)$ percentage of ovigerous females $(91.2 \pm 6.3 \%$ and $78.8 \pm$ $9.0 \%$, respectively) than other treatments.

\subsection{Nauplii production}

Temperature significantly affected nauplii production in both individual pairs $(p=0.0012)$ and in groups of pairs $(p<0.0001)$, however, the mean brood size was not affected by temperature $(p=0.8991)$ (Table 2$)$. Temperature affected the mean daily nauplii production by decreasing the amount of time required between broods (brood interval) as temperature increased. The brood interval decreased from $1.9 \pm 0.5$ days at $24^{\circ} \mathrm{C}$ to $1.3 \pm 0.1$ days at $32^{\circ} \mathrm{C}$. Water temperature of $34{ }^{\circ} \mathrm{C}$ impeded reproductive function and an analysis was not possible due to the low number of broods. In groups, a significant decrease $(p=0.0014)$ occurred in the total number of nauplii produced, once temperatures reached $32{ }^{\circ} \mathrm{C}$ (Fig. 1). For individual pairs, a significant decrease $(p<0.0001)$ in total nauplii produced only occurred at $34{ }^{\circ} \mathrm{C}$ (Table 2 ).

Table 2

Mean $(n=6)$ brood interval, size, and total nauplii production for Pseudodiaptomus pelagicus cultured in individual pairs at the six treatment temperatures.

\begin{tabular}{llll}
\hline $\begin{array}{l}\text { Temperature } \\
\left({ }^{\circ} \mathrm{C}\right)\end{array}$ & $\begin{array}{l}\text { Brood interval } \\
\text { (Days) }\end{array}$ & Brood size & Total nauplii production \\
\hline 24 & $1.9 \pm 0.5^{\mathrm{a}}$ & $16.0 \pm 4.0^{\mathrm{a}}$ & $87.8 \pm 10.7^{\mathrm{a}}$ \\
26 & $1.6 \pm 0.2^{\mathrm{ab}}$ & $14.5 \pm 4.0^{\mathrm{a}}$ & $80.8 \pm 17.3^{\mathrm{a}}$ \\
28 & $1.4 \pm 0.1^{\mathrm{ab}}$ & $15.1 \pm 3.9^{\mathrm{a}}$ & $98.7 \pm 25.8^{\mathrm{a}}$ \\
30 & $1.4 \pm 0.2^{\mathrm{b}}$ & $16.2 \pm 3.7^{\mathrm{a}}$ & $90.3 \pm 36.5^{\mathrm{a}}$ \\
32 & $1.3 \pm 0.1^{\mathrm{b}}$ & $15.1 \pm 3.0^{\mathrm{a}}$ & $86.7 \pm 37.2^{\mathrm{a}}$ \\
34 & - & $14.8 \pm 2.9^{\mathrm{a}}$ & $21.8 \pm 21.7^{\mathrm{b}}$ \\
\hline
\end{tabular}

Different superscript letters indicate statistical differences $(p \leq 0.05)$ among treatments. 


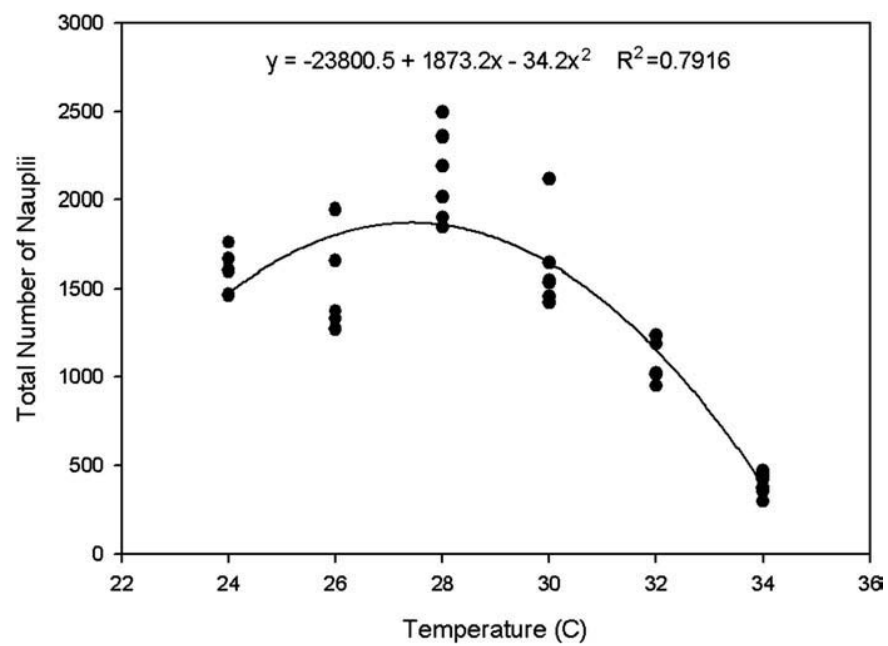

Fig. 1. Total daily nauplii (Pseudodiaptomus pelagicus) produced at the six treatment temperatures during 10 day group experiment $(n=6)$.

In the group experiment, daily nauplii production was much higher for day one when compared to all other days regardless of temperature (Fig. 2). This sharp decrease in production was followed by an increase in production for days three to six. Total nauplii production in the group experiment increased to 1861 nauplii at $27.5^{\circ} \mathrm{C}$, then declined gradually until $30^{\circ} \mathrm{C}$ before sharply decreasing (Fig. 1).

Regardless of scale, individual pairs, or groups of pairs, the trend of temperature on mean daily nauplii production was similar. Mean daily nauplii production in the individual pairs and group experiments were both highest at 28 and $30^{\circ} \mathrm{C}$. Daily production peaked at $28^{\circ} \mathrm{C}$ in the individual pair experiments, and had $9.8 \pm 2.6$ nauplii per female per day while the group experiment also peaked at $28{ }^{\circ} \mathrm{C}$ with production of $9.5 \pm 1.9$ nauplii per female per day.

\subsection{Population dynamics}

The effects of temperature on the population composition and the total number in the population were both highly significant $(p<0.0001)$ (Figs. 3 and 4). The total population was similar from 24-30 ${ }^{\circ} \mathrm{C}$ and peaked at $30^{\circ} \mathrm{C}$ with $386.8 \pm 186.5$ individuals, followed by a very large decline at $34{ }^{\circ} \mathrm{C}$ to $13.0 \pm 14.1$ individuals (Fig. 4).

The distribution of developmental stages within the population was also affected by temperature (Fig. 3). At lower temperatures, the population had a larger number of nauplii and copepodites than at higher temperatures up to $32{ }^{\circ} \mathrm{C}$; the $34{ }^{\circ} \mathrm{C}$ treatment performed poorly. The number of adults in the population reached a maximum at $30{ }^{\circ} \mathrm{C}$ before declining sharply at 32 and $34{ }^{\circ} \mathrm{C}$. Despite the overall decline in numbers, the $32{ }^{\circ} \mathrm{C}$ treatment was comprised of more advanced staged individuals than nauplii. The presence of gravid females increased with increasing temperatures and peaked at $32{ }^{\circ} \mathrm{C}$. At $34{ }^{\circ} \mathrm{C}$, the population declined greatly in number, and the distribution of life stages was no longer relevant.

\section{Discussion}

Temperature is often the most important environmental factor affecting the productivity of copepods in natural systems (Christou and Moraitou-Apostolopoulou, 1995; Siokou-Frangou, 1996). In our study of $P$. pelagicus, temperature affected survival, maturation time, the number of ovigerous females, and fecundity, but had no effect on sex ratio. Sex ratio did not deviate from the expected $1: 1$ in all treatments, which is consistent with the calanoid copepod, $G$. imparipes (Rippingale and Hodgkin, 1974). Survival and fecundity was highest at $28{ }^{\circ} \mathrm{C}$, and survival was lowest at 32 and $34{ }^{\circ} \mathrm{C}$. Fecundity was lowest at 24 and $26^{\circ} \mathrm{C}$. The percent ovigerous females followed the same trend as fecundity and was lowest at $26^{\circ} \mathrm{C}$. This may be a result of a longer interbrood duration; additionally, the time when the population was sampled may have been a time when the majority of females were between broods. Mean development time, from early nauplii to reproductive adults, decreased exponentially with increasing temperature and reached the shortest duration at $32{ }^{\circ} \mathrm{C}$. An exponential increase in development time with a corresponding decrease in temperature is well supported in the literature. The calanoid copepod, Pseudocalanus newmani, was reported to experience a doubling of development time from 20.9 to 42.3 days when temperatures decreased from 15 to $6{ }^{\circ} \mathrm{C}$ (Lee et al., 2003). This trend was also observed in A. clausi, where development time increased from 35.4 to 74.8 days when temperatures decrease from 10 to $5{ }^{\circ} \mathrm{C}$. This effect is also well documented in marine

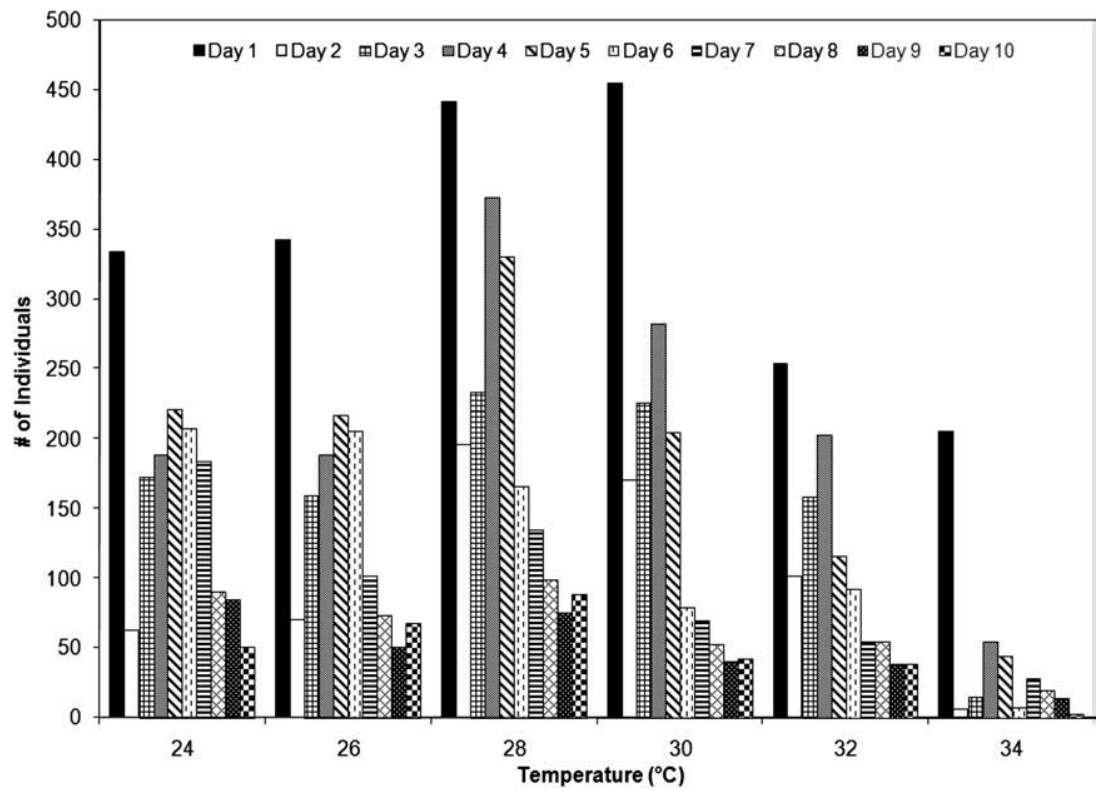

Fig. 2. Mean $(n=6)$ daily production of Pseudodiaptomus pelagicus nauplii cultured at the six treatment temperatures in groups of pairs following 10 days of culture. 


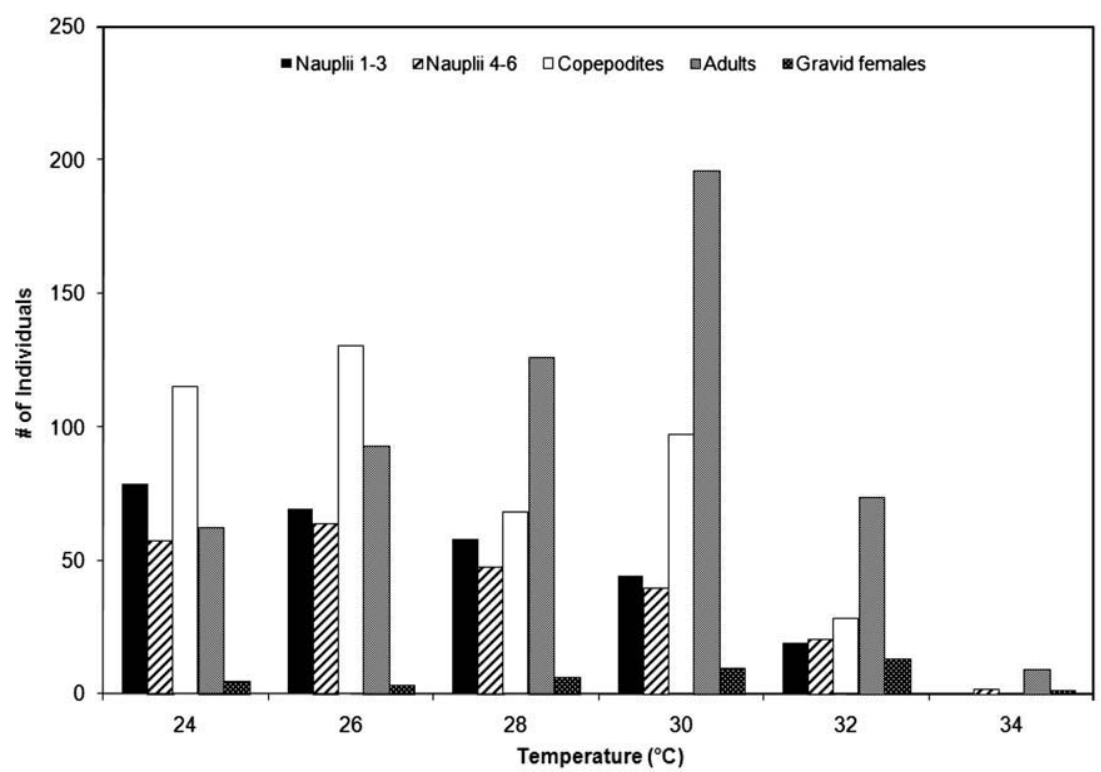

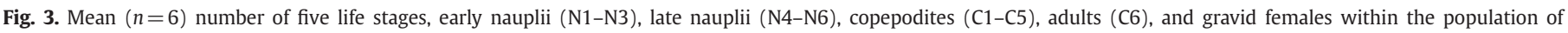
Pseudodiaptomus pelagicus cultured for 10 days at the six treatment temperatures from an initial population of 10 adult pairs.

harpacticoid copepods (Williams and Jones, 1999). As temperatures increase to the upper thermal limit of the species, the effect of temperature on development time decreases in magnitude (see Peterson, 2001 for a review).

In our study of $P$. pelagicus development, the regression curve became asymptotic at approximately $30^{\circ} \mathrm{C}$. Temperatures greater than $30{ }^{\circ} \mathrm{C}$ were detrimental to survival, percent ovigerous females, and fecundity. Culture temperatures below $28{ }^{\circ} \mathrm{C}$ had high survival and experienced lower fecundity and extended maturation time from early nauplii to adult. The optimal temperature for aquaculture purposes appears to be $30^{\circ} \mathrm{C}$, which results in the shortest duration time to adult and relatively high survivorship and fecundity.

Nauplii production from both individual pairs and groups of pairs followed similar trends with peak production at approximately $28{ }^{\circ} \mathrm{C}$. Individual pair data revealed that increased production was not due to an increase in brood size but rather a decrease in brood interval. Brood interval followed the same trend as mean development time, and exponentially increased with decreasing temperature. Brood interval at $28{ }^{\circ} \mathrm{C}$ was 1.4 days and at $34{ }^{\circ} \mathrm{C}$ thermal stress likely impeded reproduction. At $34^{\circ} \mathrm{C}$, production was lower than all other temperatures and a brood interval could not be determined, although mean brood size was similar to other temperatures. At $34{ }^{\circ} \mathrm{C}$, thermal stress resulted in more erratic production of nauplii between replicates with a range of 0 55 nauplii produced in a 10 day period. Also, a greatly reduced lifespan was observed at $34^{\circ} \mathrm{C}$ and the maximum number of observed broods was three in one replicate but production ceased after the fourth day. This may indicate thermal stress caused energy to be allocated toward survival processes and away from reproduction. This trend was reported in Tisbe battagliai, where at $25{ }^{\circ} \mathrm{C}$ nauplii production ceased after 20 days while lower temperature treatments continued to produce nauplii for 36 days (Williams and Jones, 1999). Group data confirmed this with a similar pattern of production. Daily mean nauplii production was similar in the grouped and individual pairs, and the trend remained the same. The elevated production in the group experiment on the first day suggests a possible container effect and/or possible stress of the copepods having to acclimate to experimental conditions. Despite the apparent confounding effect of the enclosure, the overall pattern remains constant in all experiments, increasing temperature increases production up to $30{ }^{\circ} \mathrm{C}$, after which as temperature increases production declines. The overall trend in the data corroborates that of the individual pairs where optimal production occurred at $26-30^{\circ} \mathrm{C}$.
Population growth and composition has recently been used to examine the effects of temperature and salinity on the aquaculture production of $A$. singiensis (Milione and Zeng, 2008). Milione and Zeng (2008) observed the highest production between $25-30{ }^{\circ} \mathrm{C}$ with a peak at $30{ }^{\circ} \mathrm{C}$ followed by a sharp decline at $34^{\circ} \mathrm{C}$. Furthermore, they related this result to the optimal temperature where mean development time was shortest and survival and egg production was highest. This is evident in our results in which the optimal observed range for production of $P$. pelagicus was $26-30{ }^{\circ} \mathrm{C}$, with the highest at the $28{ }^{\circ} \mathrm{C}$ treatment and the optimal temperature of $27.5{ }^{\circ} \mathrm{C}$ predicted by the quadratic function. Temperatures above $30^{\circ} \mathrm{C}$ elicit the sharp decline observed in Fig. 4. In addition to an increased total production, the composition of the population is directly affected by temperature. A larger proportion of the population reached maturity at $28{ }^{\circ} \mathrm{C}$ which resulted in peak performance. Above $30{ }^{\circ} \mathrm{C}$, culture performance declines and stage composition reflects the thermal stress effects.

Population growth and composition is a good indicator of potential aquaculture performance because it shows the effects of temperature on reproduction, growth, and survival. However, this method does not provide necessary data to determine the effects of temperature on

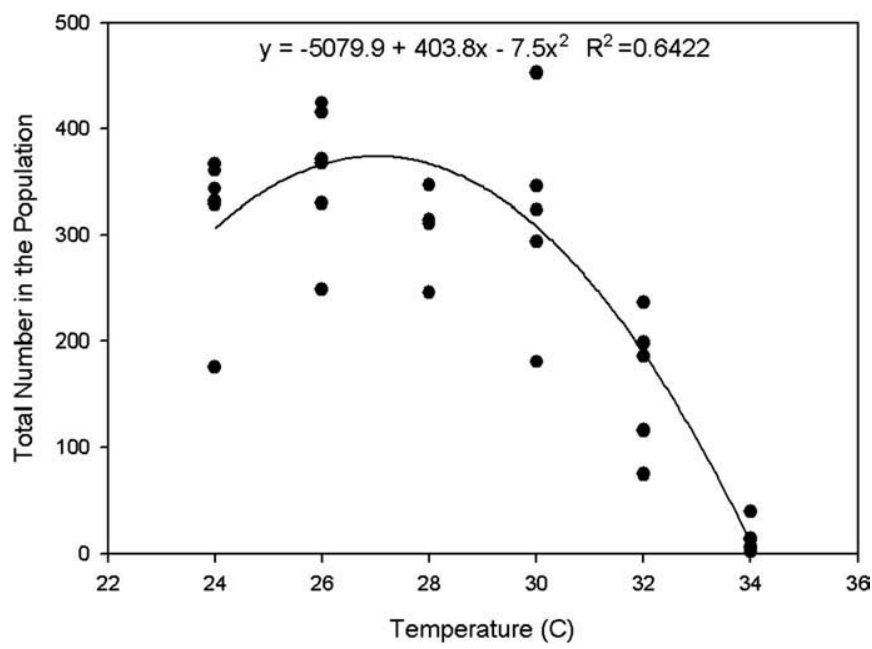

Fig. 4. Total population of Pseudodiaptomus pelagicus produced at the six treatment temperatures during the population dynamics experiment $(n=6)$. 
mean brood size or brood interval. Individual pair data showed the mean brood size was constant and the decrease in production at lower temperatures was due to the longer brood interval while at higher temperatures it was from decreases in survival and number of broods.

Experimental scale is an issue in copepod production studies. Few studies have examined production at a large commercial scale. Payne and Rippingale (2001a) examined three different production systems ranging from 60 to $1000 \mathrm{~L}$ with the peak nauplii production of $1117 / \mathrm{L} /$ day in $60 \mathrm{~L}$ batch systems compared to $520 / \mathrm{L} /$ day in $1000 \mathrm{~L}$ semi-continuous systems. It is possible that nauplii production may change when scale is increased. However, conducting replicated experiments at commercial scale can be impractical given the cost and time involved. Small scale studies, such as the present, provide valuable data concerning abiotic parameters which remain constant regardless of scale.

\section{Conclusion}

Temperature significantly affected the growth, survival, and reproductive output of the semi-benthic calanoid copepod P. pelagicus as reported for other species of calanoid (Peterson, 2001) and harpacticoid copepods (Williams and Jones, 1999). The optimal range for production was observed to be $28-30{ }^{\circ} \mathrm{C}$; this range provides for high survival, short brood interval, and decreased mean development time. Temperatures below the optimal range resulted in slower growth and longer brood intervals, which contributed to overall lower production. Additionally, temperatures above the optimal range resulted in a marked decline in production as a result of reduced survival and a decreased number of broods. Mean sex ratio and brood size were not affected by temperature.

Based upon production goals, these results provide options for commercial production. Culture water temperatures of $28-30{ }^{\circ} \mathrm{C}$ will maximize population growth and nauplii production. Temperatures from $20-24{ }^{\circ} \mathrm{C}$ will slow development and nauplii production but can be used to maintain cultures long-term with high survival while decreasing algae requirements. Manipulating temperature within a production scenario with multiple culture systems facilitates the timing of maturation and nauplii production by controlling developmental time and provides the ability to coincide or stagger the timing of nauplii production.

\section{Acknowledgements}

We thank the Florida Department of Agriculture and Consumer Services Division of Aquaculture and the University of Florida Institute of Food and Agricultural Sciences (IFAS) Research Innovation Fund Grants Program for funding this research. We thank the three anonymous reviewers for valuable comments. We also thank Scott Grabe, Matthew DiMaggio, and Shawn DeSantis for assisting with various aspects of these experiments.

\section{References}

Baensch, F., Tamaru, C., 2009. Spawning and development of larvae and juveniles of the rare blue Mauritius angelfish, Centropyge debelius (1988), in the hatchery. Journal of the World Aquaculture Society 40 (4).

Chen, Q., Sheng, J., Lin, Q., Gao, Y., Lv, J., 2006. Effect of salinity on reproduction and survival of the copepod Pseudodiaptomus annandalei Sewell, 1919. Aquaculture 258, 575-582.

Christou, E.D., Moraitou-Apostolopoulou, M., 1995. Metabolism and feeding of mesozooplankton of the eastern Mediterranean coast (Hellenic waters). Marine Ecology Progress Series 126, 39-48.

Drillet, G., Iversen, M.H., Sørensen, T.F., Ramløv, H., Lund, T., Hansen, B.W., 2006. Effect of cold storage upon eggs of a calanoid copepod Acartia tonsa Dana and their offspring. Aquaculture 254, 714-729.

Drillet, G., Lindley, L.C., Michels, A., Wilcox, J., Marcus, N.H., 2007. Improving cold storage of subitaneous eggs of the copepod Acartia tonsa Dana from the Gulf of Mexico (Florida - USA). Aquaculture Research 38, 457-466.

Gapasin, R.S.J., Duray, M.N., 2000. Effects of DHA enriched live food on growth and survival and incidence of opercular deformities in milkfish (Chanos chanos). Aquaculture 193, 49-63.

Gardner, T., 2000. Spawning and rearing the yellow dottyback, Pseudochromis fuscus. Freshwater and Marine Aquarium 23 (4), 126-132.
Grice, G.D., 1969. The developmental stages of Pseudodiaptomus coronatus Williams (Copepoda, Calanoida). Crustaceana 17, 291-301.

Hoff, F.H., Snell, T.W., 1999. Plankton Culture Manual, fifth edition. Florida Aqua Farms Inc., Dade City, FL. 160 pp.

Holste, L., Peck, M.A., 2006. The effects of temperature and salinity on egg production and hatching success of Baltic Acartia tonsa (Copepoda: Calanoida): a laboratory investigation. Marine Biology 148, 1061-1070.

Holmstrup, M., Overgaard, J., Sørensen, T.F., Drillet, G., Hansen, B.W., Ramløv, H., EngellSørensen, K., 2006. Influence of storage conditions on viability of quiescent copepod eggs (Acartia tonsa Dana): effects of temperature, salinity and anoxia. Aquaculture Research 37, 625-631.

Hunter, J., 1981. Feeding ecology and predation of marine fish larvae. In: Lasker,, R. (Ed.) Marine Fish Larvae: Morphology, Ecology, and Relation to Fisheries. University of Washington Press, Seattle, WA, pp. 33-77.

Isla, J.A., Perissinotto, R., 2004. Effects of temperature, salinity and sex on the basal metabolic rate of the estuarine copepod Pseudodiaptomus hessei. Journal of Plankton Research 26, 579-583.

Jacobs, J., 1961. Laboratory cultivation of the marine copepod Pseudodiaptomus coronatus Williams. Limnology and Oceanography 6, 443-446.

Kraul, S., Brittain, K., Cantrell, R., Nagao, T., Ako, H., Ogasawara, A., Kitagawa, H., 1993. Nutritional factors affecting stress resistance in the larval mahimahi, Coryphaena hippurus. Journal of the World Aquaculture Society 24, 186-193.

Kraul, S., Nelson, A., Brittain, K., Ako, H., Ogasawara, A., 1992. Evaluation of live feeds for larval and postlarval mahimahi Coryphaena hippurus. Journal of the World Aquaculture Society 23, 299-307.

Lee, H., Ban, S., Ikeda, T., Matsuishi, T., 2003. Effect of temperature on development, growth and reproduction in the marine copepod Pseudocalanus newmani at satiating food condition. Journal of Plankton Research 25, 261-271.

Leis, J.M., 1991. The pelagic stage of reef fishes. In: Sale, P.F. (Ed.), The Ecology of Fishes on Coral Reefs. Academic Press, San Diego, CA, pp. 183-230.

Morehead, D., 2004. Copepod culture workshop in Hawaii. Austasia Aquaculture 18 46-49.

McKinnon, A.D., Duggan, S., Nichols, P.D., Rimmer, M.A., Semmens, G., Robino, B., 2003. The potential of tropical paracalanid copepods as live feeds in aquaculture. Aquaculture 223, 89-106.

Milione, M., Zeng, C., 2008. The effects of temperature and salinity on population growth and egg hatching success of the tropical calanoid copepod, Acartia sinjiensis. Aquaculture 275, 116-123.

Østergaard, P., Munk, P., Janekarn, V., 2005. Contrasting feeding patterns among species of fish larvae from the tropical Andaman Sea. Marine Biology 146, 595-606.

Payne, M.F., Rippingale, R.J., 2001a. Intensive cultivation of the calanoid copepod Gladioferens imparipes. Aquaculture 201, 329-342.

Payne, M.F., Rippingale, R.J., 2001b. Effects of salinity, cold storage and enrichment on the calanoid copepod Gladioferens imparipes. Aquaculture 201, 251-262.

Payne, M.F., Rippingale, R.J., Cleary, J.J., 2001. Cultured copepods as food for west Australian dhufish (Glaucosoma hebraicum) and pink snapper (Pagrus auratus) larvae. Aquaculture 194, 137-150.

Peck, M.A., Holste, L., 2006. Effects of salinity, photoperiod and adult stocking density on egg production and egg hatching success in Acartia tonsa (Calanoida: Copepoda): optimizing intensive cultures. Aquaculture 255, 341-350.

Peterson, W.T., 2001. Patterns in stage duration and development among marine and freshwater calanoid and cyclopoid copepods: a review of rules, physiological constraints and evolutionary significance. Hydrobiologia 453/454, 91-105.

Rippingale, R.J., Hodgkin, E.P., 1974. Population growth of a copepod Gladioferens imparipes Thomson. Australian Journal of Marine and Freshwater Research 25, 351-360.

Sampey, A., McKinnon, A.D., Meekan, M.G., McCormick, M.I., 2007. Glimpse into guts: overview of the feeding of larvae of tropical shorefishes. Marine Ecology Progress Series 339, 243-257.

Santos, P.J.P., Castel, J., Souza-Santos, L.P., 1999. Development time of harpacticoid copepods: some empirical models and implications. Journal of the Marine Biological Association of the U.K. 79, 1123-1124.

SAS, 1999. SAS Procedures Guide, Version 8. SAS Publishing. 1624 pp.

Shields, R.J., Bell, J.G., Luizi, F.S., Gara, B., Bromage, N.R., Sargent, J.R., 1999. Natural copepods are superior to enriched Artemia nauplii for halibut larvae (Hippoglossus hippoglossus) in terms of survival, pigmentation and retinal morphology: relation to dietary essential fatty acids. Journal of Nutrition 129, 1186-1194.

Shields, R.J., Kotani, T., Augustin, M., Marion, K., Kobashigawa, J., 2003. Intensive culture of a calanoid copepod, Parvocalanus sp., and application for rearing small subtropical marine fish larvae. World Aquaculture Annual Conference, Salvador Brazil. Book of Abstracts, vol. 2. 720 pp.

Shields, R.J., Kotani, T., Molnar, A., Marion, K., Kobashigawa, J., Tang, L., 2005. Intensive cultivation of a subtropical paracalanid copepod, Parvocalanus sp., as a prey item for small marine fish larvae. In: Lee, C.S., O'Bryan, P.J., Marcus, N. (Eds.), Copepods in Aquaculture. Blackwell Publishing, pp. 209-223.

Sigma Plot, 2002. Sigma Plot Users Guide, Version 8.0. SPSS Inc. 526 pp.

Siokou-Frangou, I., 1996. Zooplankton annual cycle in a Mediterranean coastal area. Journal of Plankton Research 18, 203-223.

Støttrup, J.G., 2000. The elusive copepods: their production and suitability in marine aquaculture. Aquaculture Research 31, 703-711.

Støttrup, J.G., 2003. Production and nutritional value of copepods. In: Støttrup, J.G., McEvoy L.A. (Eds.), Live Feeds in Marine Aquaculture. Blackwell Science, Oxford, UK. 318 pp.

Suantika, G., Dhert, P., Rombaut, G., Vanderberghe, J., DeWolf, T., Sorgeloos, P., 2001. The use of ozone in a high density recirculation system for rotifers. Aquaculture 201, 35-49.

Sullivan, B.K., Costello, J.H., Van Keuren, D., 2007. Seasonality of the copepods Acartic hudsonica and Acartia tonsa in Narragansett Bay, RI, USA during a period of climate change. Estuarine, Coastal and Shelf Science 73, 259-267. 
Sun, X.H., Sun, S., Li, C.L., Zhang, G.T., 2008. The seasonal and spatial variation in abundance and egg production of Paracalanus parvus (Copepoda: Calanoida) in/ out Jiaozhou Bay, China. Estuarine, Coastal and Shelf Science 79, 637-643.

Vanderlugt, K., Lenz, P.H., 2008. Management of nauplius production in the paracalanid, Bestiolina similes (Crustacea: Copepoda): effects of stocking densities and culture dilution. Aquaculture 276, 69-77.

Walter, T.C., 1989. Review of the New World species of Pseudodiaptomus (Copepoda: Calanoida), with a key to the species. Bulletin of Marine Science 45, 590-628.
Wilcox, J.A., Tracy, P.L., Marcus, N.M., 2006. Improving live feeds: effect of a mixed diet of copepod nauplii (Acartia tonsa) and rotifers on the survival and growth of firstfeeding larvae of the southern flounder, Paralicththys lethostigma. Journal of the World Aquaculture Society 37, 113-120.

Williams, T.D., Jones, M.B., 1999. Effects of temperature and food quality of the reproduction of Tisbe battagliai (Copepoda: Harpacticoida). Journal of Experimental Marine Biology and Ecology 236, 273-290. 